Valóságos könyvtár - könyvtári valóság. Könyvtár- és információtudományi tanulmányok 2018. Szerk. Kiszl Péter, Csík Tibor.

Budapest, ELTE BTK Könyvtár- és Információtudományi Intézet. 2018. 167-179.

\title{
A LONG TAIL ÉS A KÖNYVTÁRAK HOGYAN KAPCSOLÓDHATUNK A „HOSSZÚ FAROK” JELENSÉGHEZ?
}

\section{DIPPOLD PÉTER}

FSZEK Központi Könyvtár, igazgató, ELTE BTK KITI, adjunktus

\section{TARTALMI ÖSSZEFOGLALÓ}

Bizonyára sokan ismerik Chris Anderson 2004-ben publikált üzleti modelljét, ami az internetes kereskedelem sajátosságát írja le: a nagy tömegben árusított bestseller termékek nagyságrendjét eléri a kevesebb példányban elkelő, de jóval nagyobb sokféleséggel rendelkező áruk kereskedelme, és az elektronikus forgalmazók a rendelkezésre álló dokumentumok 98\%-át évente legalább egyszer eladják vagy forgalmazzák. Ez az eloszlás, a Long Tail, az elektronikus dokumentumok esetében felülírja a fizikai világ eddig felismert eloszlási rendszereit (pl. Pareto eloszlás - a jövedelmek 80\%-át a népesség 20\%-a birtokolja, vagy Derek de Solla Price felismerése - a tudományos szerzők 25\%-a felelős a megjelent cikkek 75\%-áért). A könyvtárak ehhez a jelenséghez több ponton csatlakozhatnak. Dokumentumforgalmuk nagy részét a népszerű termékek adják, ugyanakkor a kölcsönzési statisztikákban jól követhető a ritkábban forgalmazott, de összességében nagy tömeget kiadó ún. „niche” kölcsönzések nagyságrendje. A Fővárosi Szabó Ervin Könyvtár kölcsönzési statisztikáinak ismertetésén keresztül a cikk bemutatja a közkönyvtári és szakkönyvtári funkciók különbségét. A Long Tail jelenség a könyvtári világban az e-könyvek szolgáltatásba vonásával, illetve a tömeges digitalizálással nyeri el valódi helyét.

\section{Chris Anderson új ü̊leti modellje}

Az üzleti modell első megfogalmazója, mondhatjuk felfedezője Chris Anderson, a Wired Magažin szerkesztője volt. 2004-ben jelent meg „The Long Tail” címú cikke", amely a webkereskedelem résztvevői, majd nem sokkal később a könyvtárosok körében is nagy feltűnést keltett. Anderson cikkében arra hívja fel a figyelmet, hogy az interneten történő forgalmazás egészen más törvényszerűségek alapján múködik, mint a hagyományos. Internetes kultúraterjesztő vállalkozások üzleti eredményeinek vizsgálata nyomán mutatott rá arra a tényre, hogy a virtuális kereskedések bevételeinek jó részét nem a nagy tömegben terjesztett, de korlátozott féleségű népszerű árucikkek (pl. sikerfilmek, bestsellerek, slágerek) adják, hanem az egyszerre kevesebb ember érdeklődésére számot tartó, ugyanakkor az aktuális divatos cikkeknél sokkal többféle egységek eladása. A hagyományos árucikkek (pl. nyomtatott könyvek) esetében a kevésbé eladható, „kifutott" cikkek raktározási és terjesztési költségei hosszabb távon nem teszik gazdaságossá 


\section{DIPPOLD PÉTER}

a készletek fenntartását. Ezzel szemben a nagy internetes terjesztők esetében ezek a költségek nem meghatározók, ezért érdemes megtartani a kevésbé népszerű termékek forgalmazását is. Az alacsonyabb keresettségű termékek (azaz a Long Tail) eladásából, terjesztéséből keletkezett bevétel összességében elérheti a viszonylag kisebb féleségű divattermék forgalmazásából származó bevételt.



1. ábra: A Long Tail diagramon ábrázolva

Az internet tehát alapvetően megváltoztatja a piacot: bárki lehet kiadó, blogok, portálok fenntartója, vagy akár magányos múvész, így demokratizálódik a forgalmazás. A széles kínálat fenntartása megéri a kereskedelmi forgalmazónak is, ezért a fogyasztó értelemszerűen nagyobb választékból válogathat. ${ }^{3}$ Ezt az üzleti modellt követik a legnagyobb elektronikus kereskedelemmel foglalkozó cégek is, mint pl. az Amazon, a Netflix vagy a Google is.

Anderson vizsgálatai alapján az elektronikus forgalmazók a rendelkezésre álló dokumentumok 98\%-át évente legalább egyszer eladják vagy forgalmazzák. Ez az eloszlás az elektronikus dokumentumok esetében felülírja a fizikai világ eddig felismert eloszlási rendszereit, pl. a Pareto-eloszlást, amely szerint a különböző jelenségek következményeinek 80\%-a az okok 20\%-ára vezethetőek vissza. Pareto 1906-ban bebizonyította, hogy Milánó lakossága jövedelmeinek 80\%-át a népesség 20\%-a birtokolja. Ezt az elvet később 80/20-as szabályként általánosították és kiterjesztették az élet különböző területeire. Manapság főleg az üzleti menedzsmentben és a minőségbiztosításban éli reneszánszát. 


\section{A Long Tail és a könyvtárak.}

A Long Tail - mint statisztikai törvényszerűség - valamennyi hatványfüggvény-eloszlásra érvényes, még ha nem is 98\%-os szabályként: egy „hosszú farok” jelenik meg, az eloszlás lapos, messze elnyúló vége, ahol - ha rangsorrend eloszlást készítünk - azok a könyvek vannak, amiket egyetlen példányban adtak el, azok a szavak, amik csak egyszer szerepelnek egy korpuszban, azok az emberek, akiknek minimális a jövedelme, vagy azok a szerzők, akiknek csupán egyetlen publikációja van. ${ }^{4}$ (1. ábra)

Anderson üzleti modellje szinte megjelenése pillanatától felkeltette a könyvtári szakma érdeklődését is. A cikk nyomán elinduló viták főleg arra tértek ki, hogy az egyes könyvtári rendszerek összességükben főképpen a „Long Tail” ún. „niche” kategóriájába tartozó dokumentumokat tartalmaznak. A könyvtárak gyűjteményei globálisan a legnagyobb változatosságban tartalmazzák az emberiség kultúrájának írott emlékeit, amelyből a használók kedvük, érdeklődésük vagy szükségleteik szerint válogathatnak. ${ }^{6}$ A dokumentumok megtalálásához a kaput a könyvtárak katalógusai jelentik. Ugyanakkor a katalógusok használata nem jelenti automatikusan maguknak a dokumentumoknak az elérését, ehhez a könyvtári rendszer(ek) további szolgáltatásait kell igénybe venni (helyi, illetve könyvtárközi kölcsönzés vagy digitalizálás). Ez pedig - beláthatjuk - aligha veheti fel a versenyt a különböző adatbázisok egy-két kattintással elérhető fulltextes kínálatával.

Mint Lorcan Dempsey, az OCLC korábbi elnökhelyettese megfogalmazta: Nem elégséges az anyagokat a rendszeren belül megjeleníteni, valóságosan is hozzáférhetőnek kell lenniük (minden olvasónak a saját könyvét a ranganathani fogalom értelmében), a potenciális érdeklődő olvasónak meg kell ismerni a könyv létezését (minden könyvnek a saját olvasóját), az igényt és annak teljesítését összekötő rendszernek hatékonynak kell lenni (óvd az olvasó idejét).

\section{Long Tail a tudománymetriában}

Köztudott, hogy a tudománymetria számos elve a hatványfüggvény-eloszláson alapul. Ilyen pl. Lotka törvénye, ami kimondja, hogy a tudományos szerzők kb. 60\%-a egy publikációval, 15\%-a kettővel, míg csupán 7\%-a rendelkezik három publikációval (és így tovább). Derek de Solla Price fogalmazta meg elsőként az 1960-as években, hogy a tudományos publikációk szerzőinek mindössze 25\%-a felelős a megjelent közlemények 75\%-áért, és ugyanez az eloszlás érvényes a hivatkozásokra is. Modellje szerint a publikációk korábbi sikerük arányában, hólabdaszerűen vonzzák magukhoz az újabb és újabb idézéseket. Bár nem tudománymetriai indíttatásból, de ehhez a jelenséghez kapcsolódik Barabási Albert László hálózati elmélete, amely bebizonyította, hogy a hálózatok nem véletlenszerűek, hanem skálafüggetlen hálóként múködnek, tehát erôs csomópontok léteznek a hálókon belül. Ha egy új elem kapcsolódik a hálóhoz, nem véletlenszerűen kapcsolódik valahova, hanem a „népszerű” csomópontokat keresi, és hatványfüggvényeloszlást követ. Az elmélet valamennyi hálózatra (biológiai, társadalmi, 


\section{DIPPOLD PÉTER}

közösségi stb.) érvényes. Barabási eredetileg angolul megjelent, bestsellerré vált könyvét több nyelvre fordították le. ${ }^{8}$

\section{Long Tail-vizsgálatok és keresési stratégiák}

A könyvtári katalógusoknak alapvető szerepük van abban, hogy biztosítsák a gyújteményekben őrzött dokumentumok elérését. Több kutatás is foglalkozott a Long Tail jelenség kapcsán a keresési eredmények mérésével. Az edmontoni közkönyvtárban (Edmonton Public Library) például az aktuális témában folytatott keresések és a valóban megtörtént események közötti összefüggéseket elemezték négy hónap keresési adatainak felhasználásával. Az eredmények alátámasztják a Long Tail elméletet: az aktuális témákra folytatott keresések az összes keresés nagy többségét alkotják, és a megtörtént események hatást gyakorolnak az ilyen típusú keresések gyakoriságára. ${ }^{9}$

Egy másik kutatás a webtartalmak eloszlását vizsgálta abból a szempontból, hogy a kis számú, de óriási mennyiségű tartalommal rendelkező nagy keresőrendszerek (pl. a Google), közösségi hálók (Facebook) és online enciklopédiák (Wikipédia) főképpen a kereskedelmi szempontból életképes tartalmakra összpontosítanak. Ezzel szemben állnak a nagy számban létező (a Long Tail elnyúló részét alkotó), de jóval szúkebb tartalommal rendelkező szolgáltatók, ebbe a körbe tartoznak a nemzeti és a digitális könyvtárak, illetve a repozitóriumok is. A tanulmány a tudományos és oktatási tartalmak láthatóbbá tétele érdekében EEXCESS néven egy olyan módszert javasol bevezetni, amely a speciális tartalmakat perszonalizálva, ajánlásokkal ellátva juttatja el a használókhoz. ${ }^{10}$

\section{A Long Tail jelenség alkalmazása a könyvtárak gyüjteményszervezésében}

A könyvtárak állományaik használatának elemzése során számtalan formában találkoznak a Long Tail jelenséggel. A külföldi publikált vizsgálatok között találkozhatunk az e-folyóiratok használatára és előfizetési gyakorlatára vonatkozó elemzéssel, ${ }^{11}$ egy adott könyvtárban megtalálható orvosi szakfolyóiratok korábbi évfolyamainak használatáról szóló vizsgálattal, ${ }^{12}$ vagy annak feltárásával, hogyan érhetők el a leghatékonyabban egy digitális könyvtár gyarapításában a csak weben megjelenő elektronikus tartalmak. ${ }^{13}$ Mindezek a kutatások a Long Tail statisztikai módszereinek felhasználásával zajlottak.

\section{A Long Tail jelenség a Fövárosi Szabó Ervin Könyvtár kölcsönzési statisztikáiban}

A Fővárosi Szabó Ervin Könyvtárnak - mint köztudott - összesen 49 tagkönyvtára van. A hálózati könyvtárak területi alapon három régióba szervezve végzik munkájukat, a Központi Könyvtár külön szervezeti egységet képez. A közkönyvtári ellátást a FSZEK tagkönyvtárai együtt biztosítják Budapest területén. Az országos szakkönyvtári feladatok ellátásáért a Központi Könyvtár felel. ${ }^{14}$ Ezen két alapfunkció jól elkülöníthető a kölcsönzési statisztikákban is. 
A kölcsönzési adatok fontos információkat nyújtanak az állomány használatáról, elemzésük alkalmat ad az állomány folyamatos alakítására. A kölcsönzési statisztikákat természetesen nem csak a rendelések alátámasztására lehet használni. Segítségükkel sikerlistákat lehet felállítani, egy adott szakterület, vagy akár egyetlen könyv egy kiadásának kölcsönzöttségét is lehet vizsgálni, a könyvek raktárba kerülését, a rendszeren belüli átirányítását vagy törlését is alátámaszthatja a statisztikák elemzése. Ezeken kívül számos speciális információ nyerhető ki segítségükkel a kérdés megfogalmazásának függvényében.

A kölcsönzések számának alakulása a legjobb mérőszám a Long Tail „fejének” és „farkának” azonosítására, és ezzel a beszerzések, a törlések, az egyes dokumentumok vagy állományrészek intézményi szintű átirányításának koordinálására.

A következő kölcsönzési statisztikák célja a Long Tail jelenség bemutatása mellett a FSZEK köz- és szakkönyvtári funkcióiból adódó különbségek érzékeltetése. A táblázatok (2-3. ábra) a könyvtárak kölcsönzéseirôl pillanatképet adnak, de nem tartalmaznak elemzéseket. Az összehasonlíthatóság érdekében a hálózati könyvtárak és a Központi Könyvtár esetében ugyanazokat az időhatárokat és kritériumokat adtam meg: melyek azok a kölcsönözhető könyvek, amiket a használók a 2015. január 1-je és 2017. július 1-je közötti időszakban húsznál többször kölcsönöztek? A lekérdezésben szerepelt, hogy az adott művet összesen hányszor kölcsönözték ki ebben az időszakban, hány példányban található meg a könyvtárban, illetve egy példányra átlagosan hány kölcsönzés esik. A sorrend kialakításakor az utolsó két szempontot nem vettem figyelembe, mert célom itt a legnépszerűbb művek bemutatása volt. A példányszám és az egy példányra jutó kölcsönzöttség azonban releváns lehet más célok megfogalmazása, pl. egy pótrendelés esetében.

\section{Pillanatkép a hálózati kölcsönzési statisztikáról (2015. január 1. - 2017. július 1.)}

A hálózati könyvtárak esetében a keresés egy több mint 16 ezer művet tartalmazó excel táblát eredményezett. A mérőpontokat a kölcsönzések számának hozzávetőleges felezésével állapítottam meg (1000-500-250-125-62-20).

\begin{tabular}{|l|r|r|}
\hline \multicolumn{1}{|c|}{ Kategória } & Kölcsönzések száma & Müvek száma \\
\hline Head 1 & 1000-2963 & 110 \\
\hline Head 2 & $500-999$ & 1174 \\
\hline Head 3 & $250-499$ & 2999 \\
\hline Long tail 1 & $125-249$ & 6066 \\
\hline Long tail 2 & $62-124$ & 9938 \\
\hline Long tail 3 & $20-61$ & 16125 \\
\hline
\end{tabular}

2. ábra: Hálózati kölcsönzések sqámokban 


\section{DIPPOLD PÉTER}

A kölcsönzések megoszlása diagramon ábrázolva a következő képet mutatja:



3. ábra: Hálózati kölcsönzések 2015-2017

A következő táblázatban az első huszonöt leggyakrabban kölcsönzött könyv listáját látjuk a hálózatban (2963-1332 kölcsönzés)

\begin{tabular}{|l|l|l|}
\hline \multicolumn{1}{|c|}{ Szerző } & \multicolumn{1}{|c|}{ Cím } & $\begin{array}{c}\text { Kölcsönzések } \\
\text { száma }\end{array}$ \\
\hline Molnár Ferenc & A Pál utcai fiúk & 2963 \\
\hline Mikszáth Kálmán & Szent Péter esernyője & 2060 \\
\hline Berg Judit & Rumini & 2052 \\
\hline Gárdonyi Géza & Egri csillagok & 1885 \\
\hline Kinney, Jeff & $\begin{array}{l}\text { Egy ropi naplója : Greg Heffley feljegyzései : } \\
{[\text { képregény] }}\end{array}$ & 1627 \\
\hline $\begin{array}{l}\text { Rowling, Joanne } \\
\text { Kathleen }\end{array}$ & Harry Potter és a Titkok Kamrája & 1625 \\
\hline Frei Tamás & $\begin{array}{l}\text { Agrárbárók : Magyarország az oroszok } \\
\text { csapdájában : [André-sztori IV.] }\end{array}$ & 1610 \\
\hline Kästner, Erich & A két Lotti & 1561 \\
\hline Kästner, Erich & Emil és a detektívek & 1520 \\
\hline Lázár Ervin & A Négyszögletú Kerek Erdó & 1480 \\
\hline Kinney, Jeff & Egy ropi naplója : az utolsó szalmaszál & 1422 \\
\hline & $\begin{array}{l}\text { Örökké [Leiner Laura: A Szent Johanna gimi } \\
\text { része] }\end{array}$ & 1416 \\
\hline Szabó Magda & Abigél & 1411 \\
\hline
\end{tabular}


A LONG TAIL ÉS A KÖNYVTÁRAK. HOGYAN KAPCSOLÓDHATUNK...

\begin{tabular}{|l|l|l|}
\hline $\begin{array}{l}\text { Rowling, Joanne } \\
\text { Kathleen }\end{array}$ & Harry Potter és az azkabani fogoly & 1389 \\
\hline Bálint Ágnes & Szeleburdi család & 1384 \\
\hline Bartos Erika & Bogyó és Babóca a levegóben & 1380 \\
\hline Marék Veronika & Boribon autózik & 1363 \\
\hline Bartos Erika & Anna és Peti : irány az óvoda! & 1353 \\
\hline Kinney, Jeff & Egy ropi naplója : kutya egy idő & 1353 \\
\hline Bartos Erika & Bogyó és Babóca : évszakos könyv & 1352 \\
\hline Radnóti Miklósné & Napló, 1935-1946 & 1344 \\
\hline Wass Albert & A funtineli boszorkány & 1341 \\
\hline Bartos Erika & Bogyó és Babóca alszik & 1332 \\
\hline Bartos Erika & Bogyó és Babóca a jégen & 1332 \\
\hline
\end{tabular}

4. ábra: A leggyakrabban kölcsönzött könyvek a bálózatban

A leggyakrabban kölcsönzött művek közül csak az első huszonötöt foglaltam a táblázatba (4. ábra). Fontosnak tartom megjegyezni, hogy ez a huszonöt cím a Long Tail „head” kategóriájának is csak a csúcsa, már a diagram első mérőpontja is 1000 múvet takar, amelyek bemutatása terjedelmi okokból természetesen nem fér a cikk keretei közé. Második megállapításom, hogy a táblázatban szereplő múvek kölcsönzöttsége semmiképpen nem jelent rangsorrendet, látható, hogy sok esetben csak néhány kölcsönzés választja el őket egymástól, tehát a sorrend akár egyetlen szempont (pl. az időhatárok) módosításakor is változhat.

Az intézményi kölcsönzési statisztikák teljes körű, mélyebb elemzése akár egy doktori disszertáció témája is lehetne. Jelen esetben ez nem cél, de ez a néhány adat is lehetôséget ad annak megállapítására, hogy egy tipikus közkönyvtárban milyen mútípusok kölcsönzése a legnépszerübb.

Feltûnő a gyerekkönyvek magas aránya a listában. Ennek több oka lehet, ezek közül emelek ki néhányat. A 2016-os statisztika szerint a gyerekolvasók (0-14 éves korig) aránya a FSZEK használói között 20\% (47 578 fó), akik összesen 777678 dokumentumot kölcsönöztek. ${ }^{15}$ Mivel számukra a kölcsönzés ingyenes, a szülők szívesen hozzák a könyvtárba a gyerekeket. Meg kell említeni a hálózati könyvtárak élő kapcsolatrendszerét a körzetükbe tartozó iskolákkal, valamint a rendszeres gyerekfoglalkozásokat, amelyek erősítik az önálló könyvtárhasználatot. A gyerek- és ifjúsági könyvek magas arányának másik oka, hogy felismerve az érdeklődést, a könyvtárak viszonylag nagy példányszámban szerzik be ezeket a múveket. A listát 4760 kölcsönzéssel vezetô Pál utcai fiúk pl. 248, míg a Két Lotti 257 példánya érhető el a hálózat könyvtáraiban. 


\section{DIPPOLD PÉTER}

Szintén az ifjúságnak, de nem a legfiatalabb korosztálynak szólnak a klasszikus kötelező olvasmányok, amit előszeretettel kölcsönöznek a fiatalok. Így kerülhetett a lista elejére $A$ Pál utcai fuík, a Szent Péter esernyöje és Az egri csillagok.

Frei Tamás könyve tipikus bestseller, ami valószínúleg rövidebb ideig tarthat érdeklődésre számot. A hálózati könyvtárakban csak 62 példánya van állományban, ezért igen magas átlagos kölcsönzöttség (26) jut egy példányra. Megjegyzem, hogy a könyvkiadás is reagált a könyv keresettségére, 2014-ben egyedül ez a könyv jelent meg 100 ezer feletti példányszámban. ${ }^{16}$

Az első huszonötbe került a megjelenésekor nagy érdeklődést kiváltó Radnóti Miklósné naplója és Wass Albert Funtineli boszorkányok címú regénye.

\section{Ami a táblázatból kimaradt}

A diagram legmeredekebb része, azaz az adott időszakban legalább 1000-szer kölcsönzött könyvek listája több mint 1000 címet tartalmaz. Ennek csak a töredékét tudtam a táblázatban bemutatni. A teljesség igénye nélkül néhány további jellemző példával lehet illusztrálni a 48 hálózati könyvtár által nyújtott legnépszerűbb kínálatot.

1240 kölcsönzéssel rendelkezik Dragomán György Fehér király című regénye, Péterfy Gergely Kitömött barbár címú könyvét 1094 olvasó kölcsönözte ki, Moldova György Az utolsó töltény címú önéletrajzát 1030-an, tehát a kortárs magyar szépirodalom iránti érdeklődés egyértelműen kimutatható.

A szórakozást szolgálja a krimi műfaja, ami bőségesen reprezentált a diagram fejrészében. Első képviselője Jo Nesbø Fehér éjszaka című krimije 1195 kölcsönzéssel, de szinte a sarkára lép Agatha Christie Tí kicsi négere 1167 kölcsönzéssel.

Az első ezer cím további megoszlása rendkívül változatos: a klasszikus magyar és külföldi szépirodalom mellett tini-könyveket, sci-fiket, kalandregényeket találhatunk a listában. A kölcsönzések mélyebb elemzésére itt nem kerülhet sor.

\section{Pillanatkép a Kö̈ponti Könyvtár kölcsönzési statisztitkájáról \\ (2015. január 1. - 2017. július 1.)}

A Központi Könyvtár esetében a keresés egy több mint 39 ezer művet tartalmazó excel táblát eredményezett. A mérőpontokat a kölcsönzések számának hozzávetőleges felezésével állapítottam meg (450-225-112-56-28). (5-6. ábra)

\begin{tabular}{|l|l|l|}
\hline \multicolumn{1}{|c|}{ Kategória } & Kölcsönzések száma & Müvek száma \\
\hline Head 1 & $450-992$ & 20 \\
\hline Head $\mathbf{2}$ & $225-449$ & 122 \\
\hline Head 3 & 112-224 & 919 \\
\hline
\end{tabular}


A LONG TAIL ÉS A KÖNYVTÁRAK. HOGYAN KAPCSOLÓDHATUNK...

\begin{tabular}{|l|l|l|}
\hline Long tail 1 & $56-111$ & 4323 \\
\hline Long tail 2 & $20-55$ & 39472 \\
\hline
\end{tabular}

5.ábra: A Központi Könyvtár köllcsönzései sqámokban

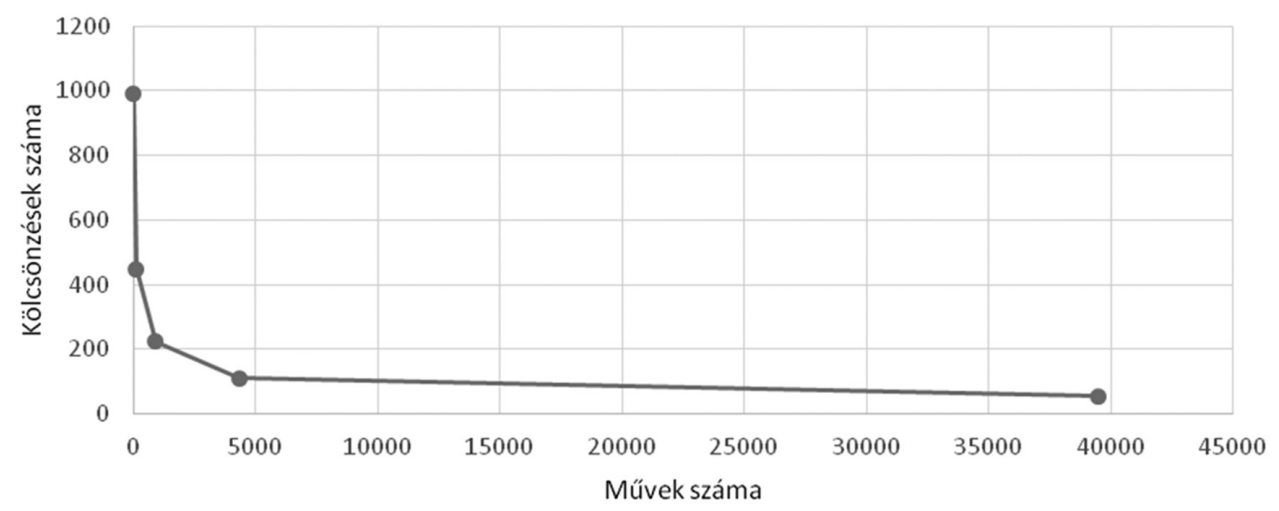

6. ábra: A Központi Könyvtár kölcsönzései 2015-2017

Az első huszonöt leggyakrabban kölcsönzött könyv a Központi Könyvtárban (992-412 kölcsönzés). (7. ábra)

\begin{tabular}{|l|l|l|}
\hline \multicolumn{1}{|c|}{ Szerző } & \multicolumn{1}{|c|}{ Cím } & $\begin{array}{c}\text { Kölcsönzések } \\
\text { száma }\end{array}$ \\
\hline Babbie, Earl R. & A társadalomtudományi kutatás gyakorlata & 992 \\
\hline & Pszichológia & 717 \\
\hline Smith, Eliot R. & Szociálpszichológia & 652 \\
\hline Mérei Ferenc & Gyermeklélektan & 620 \\
\hline Cole, Michael & Fejlódéslélektan & 590 \\
\hline Yazawa Ai & Nana & 576 \\
\hline $\begin{array}{l}\text { Csíkszentmihályi } \\
\text { Mihály }\end{array}$ & $\begin{array}{l}\text { Flow: az áramlat: a tökéletes élmény } \\
\text { pszichológiája }\end{array}$ & 567 \\
\hline Andorka Rudolf & Bevezetés a szociológiába & 564 \\
\hline Berne, Eric & Emberi játszmák & 537 \\
\hline & Általános pszichológia & 535 \\
\hline & Európa ezer éve: a középkor & 533 \\
\hline Eco, Umberto & Hogyan írjunk szakdolgozatot? & 530 \\
\hline Romsics Ignác & Magyarország története a XX. században & 528 \\
\hline
\end{tabular}




\section{DIPPOLD PÉTER}

\begin{tabular}{|l|l|l|}
\hline $\begin{array}{l}\text { García Márquez, } \\
\text { Gabriel }\end{array}$ & Száz év magány & 524 \\
\hline Foucault, Michel & A szexualitás története & 504 \\
\hline Aronson, Elliot & A társas lény & 498 \\
\hline Murakami Haruki & 1 Q84 : ezerkülöncszáznyolcvannégy & 459 \\
\hline Szabó Magda & Az ajtó & 457 \\
\hline Orwell, George & 1984 & 448 \\
\hline Forgas, Joseph P. & A társas érintkezés pszichológiája & 431 \\
\hline Ottlik Géza & Iskola a határon & 428 \\
\hline Gyáni Gábor & $\begin{array}{l}\text { Magyarország társadalomtörténete a } \\
\text { reformkortól a második világháborúig }\end{array}$ & 425 \\
\hline Mann, Thomas & A varázshegy & 418 \\
\hline Carver, Charles S. & Személyiségpszichológia & 409 \\
\hline
\end{tabular}

7. ábra: A leggyakrabban kölcsönzö̈tt könyvek a Központi Könyvtárban

Hasonlóan a hálózati statisztikánál elmondottakhoz, a sorrend a Központi Könyvtár esetében sem jelent rangsort. Az első huszonöt könyv listája ebben az esetben is csak általános megjegyzéseket indukálhat. A hálózati könyvtárakhoz mérten kisebb a kölcsönzések száma, de ez egyértelmúen visszavezethető arra, hogy itt egyetlen gyújtemény, míg a hálózati könyvtárak esetében 48 könyvtár összesített kölcsönzési száma szerepel.

Míg a hálózati könyvtárakban a gyerekkönyvek magas aránya tủnt fel, a Központi Könyvtárban hasonlóan kiemelkedő a szakkönyvek aránya az első huszonöt legkölcsönzöttebb könyv között. Ez egyértelműen a szakkönyvtári funkciónak köszönhető: a könyvtár gyarapítási politikája a szakkönyvek nagyobb példányszámú beszerzésére irányul, a magasabb példányszám pedig egyértelmúen növeli az egyes művek kölcsönzöttségét. Persze ez visszafelé is igaz, hiszen az érdeklődés miatt kerül sor a példányszám emelésére. A legkölcsönzöttebb A társadalomtudományi kutatás gyakorlata címú mú 55 példányban, a Szociálpszichológia 42, Andorka Rudolf Bevez̨etés a szociológiába címú könyve pedig 51 példányban található meg a könyvtár állományában.

A szakkönyvek a könyvtár gyújtőkörének megfelelően kizárólag társadalomtudományi területeket fednek le, ezen belül a pszichológia, a társadalom- és történeti tudományok dominálnak. Nem elhanyagolható a kölcsönzöttség nagyságrendje szempontjából az egyetemi kötelező olvasmányok magas aránya: a Központi Könyvtár látogatóinak mintegy negyven százaléka egyetemi hallgató, ez az arány - mint az alábbi diagramon látható - folyamatos emelkedést mutat, és ez természetesen döntően befolyásolja a könyvtár szerzeményezési politikáját. (8. ábra) 
A LONG TAIL ÉS A KÖNYVTÁRAK. HOGYAN KAPCSOLÓDHATUNK...

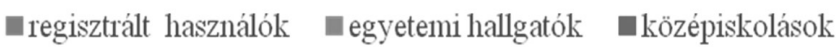

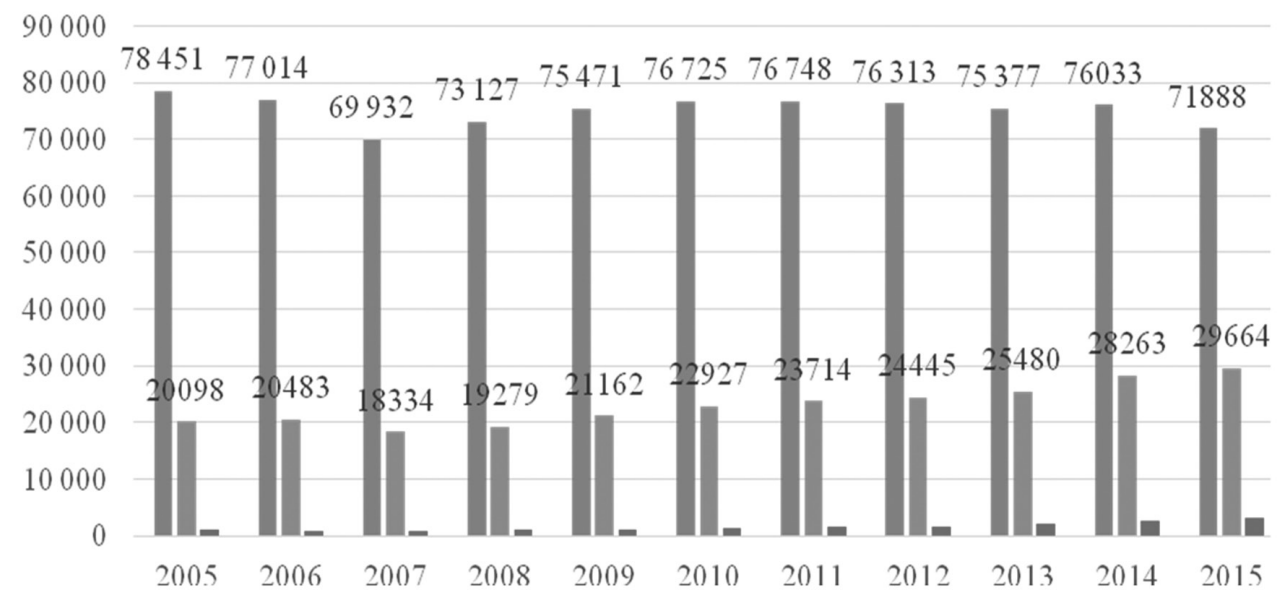

8. ábra: Egyetemi hallgatók és középiskolások aránya a Központi Könyvtárban

A listában megjelenik a szépirodalom, amit Marquez, Szabó Magda, Ottlik Géza, Thomas Mann és Murakami Haruki japán író regénytrilógiája képvisel.

A történettudományt Romsics Ignác Magyarország története a XX. században (528 kölcsönzés) és Gyáni Gábor Magyarország társadalomtörténete a reformkortól a második világbáborúig (425) reprezentálja.

A hálózati könyvtárak listájában a bestseller kategóriát Frei Tamás könyve képviselte, a Központi Könyvtárban egy tinédzsereknek szóló képregény-sorozatot sorolhatunk ebbe a kategóriába: Yazawa Ai Nana címú mangáját, ami 44 példányban található meg az állományban.

\section{Ami a táblázatból kimaradt}

Az első huszonöt után a kölcsönzöttségben természetesen folytatódik a társadalomtudományi dominancia, de újabb tudományterületek jelennek meg: pl. a filozófia, a kommunikációelmélet, a nyelvtudomány.

A hálózati könyvtárakhoz hasonlóan a kortárs magyar irodalom kölcsönzöttsége itt is magas: Dragomán György Fehér királya a sorban a 35. helyen 364 kölcsönzéssel áll, míg Kertész Imre Sorstalansága 331 kölcsönzéssel a 49. helyet foglalja el.

A szórakoztató és ismeretterjesztő irodalom kölcsönzése a Központi Könyvtárban kevésbé kiugró, mint a hálózatban. Ennek elsődleges oka a példányok kisebb száma, ami azonban tudatos gyarapítási politika eredménye: míg a kisebb könyvtárakban az érdeklődés elsősorban a szórakozás és a tanulás felé fordul, addig a Központi Könyvtár 


\section{DIPPOLD PÉTER}

a szakirodalom minél szélesebb körű beszerzésére koncentrál. Ez természetesen nem jelenti azt, hogy a Long Tail alsóbb régióiban a közkönyvtári funkcióiból következő népszerű irodalom kölcsönzése ne lenne meghatározó, csak ezek nem a kölcsönzési statisztika élén találhatók.

\section{Összegzés}

Chris Anderson az elektronikus dokumentumokra, illetve az azokat forgalmazó kereskedelemre dolgozta ki üzleti modelljét. Az elmúlt tíz év szakirodalmát áttekintve kijelenthető, hogy - bár egyes részterületeken a könyvtárak alkalmazzák a modellt - a 98\%os szabály elsősorban az elektronikus dokumentumok területén érvényes. Ha azonban a Long Tailt nem csak erre a jelenségre (98\%-os szabály) szúkítjük, a hatványfüggvényeloszlás a könyvtári szakma számos területén hasznosítható.

Ilyen példának tekinthető a Fővárosi Szabó Ervin Könyvtár kölcsönzési statisztikáinak vizsgálata is. A hálózati könyvtárak és a Központi Könyvtár kölcsönzéseirôl készült pillanatkép adatokkal bizonyítja a szakkönyvtári és közkönyvtári funkcióból adódó különbségeket.

A 2004 óta eltelt időszak bebizonyította, hogy a Long Tail mint üzleti modell kiteljesedését a könyvtárak számára a teljes körü digitalizálás jelenti. Erre azonban sokat kell még várni.

\section{Jegyzetek és irodalom}

1. ANDERSON, Chris: The Long Tail. Forrás: https://www.wired.com/2004/10/tail [2018. január 18.]. Az eredeti cikk kibővített változata könyv formában is megjelent, ennek magyar nyelvú fordítása: ANDERSON, Chris: Hosszú farok. A végtelen választék átírja az üzlet szabályait. Budapest, HVG, 2007. 266 p.

2. VAN BORM, Julien: The Long Tail, Copyright and Libraries. = Liber Quarterly, 19. vol. 2. no. 2009. 123. p. Forrás: https://doi.org/10.18352/lq.7956

3. DIPPOLD Péter: Merre tovább, katalógus? = Könyvtári Figyelő, 16. (52.) évf. 4. sz. 2006. 521527. p. Forrás: http://epa.oszk.hu/00100/00143/00061/dippold.html [2018. január 18.]

4. Bevezetés a tudományfilozófiába. Gulyás László, Kampis György, Kutrovátz Gábor, Ropolyi László, Soós Sándor, Szegedi Péter (2013) Eötvös Loránd Tudományegyetem. Forrás: http:// www.tankonyvtar.hu/hu/tartalom/tamop412A/2011-0073_bevezetes_tudomanyfilozofiaba/ ch04s02.html [2018. január 18.]

5. niche: szűk piaccal rendelkező termék.

6. DIPPOLD Péter i.m. 522. p. Forrás: http://epa.oszk.hu/00100/00143/00061/dippold.html [2018. január 18.]

7. DEMPSEY, Lorcan: Libraries and the long tail. Some thoughts about libraries in a Network Age. = D-Lib Magazine, 12. vol. 4. no. 2006. Forrás: http://www.dlib.org/dlib/april06/ dempsey/04dempsey.html [2018. február 10.]; https://doi.org/10.1045\%2Fapril2006Dempsey [2018. július 27.] 
8. Legújabb magyar kiadása: BARABÁSI Albert László: Behálózva. A hálózatok új tudománya: hogyan kapcsolódik minden egymáshoz, és ez mit jelent a tudományban, az üzleti és a mindennapi életben. Budapest, Libri, 2016. 320 p.

9. OLIPHANT, Tamil - SHIRI, Ali: The long tail of search and topical queries in public libraries. = Library Review, 66. vol. 6/7. no. 2017. 430-441. p. Forrás: https://doi. org/10.1108\%2Flr-11-2016-0097 [2018. július 27.]

10. SEIFERT, Christin - GRANITZER, Michael: EEXCESS: Personalisierter Zugriff auf LongTail-Inhalte - neue Methoden zur Verbreitung wissenschaftlich-kulturellen Wissens. - Information. = Wissenschaft und Praxis, 66. vol. 2/3. no. 2015. 103-110. p. Forrás: https://doi. org/10.1515\%2Fiwp-2015-0022 [2018. július 27.]

11. SCHÖPFEL, Joachim - LEDUC, Claire: Big deal and long tail: e-journal usage and subscriptions. = Library Review, 61. vol. 7. no. 2012. 497-510. p. Forrás: https://doi.org/10.1108 $\% 2 F 00242531211288245$. [2018. július 27.]

12. STARR, Susan - WILLIAMS, J.: The long tail: a usage analysis of pre-1993 print biomedical journal literature. $=$ Journal of the Medical Library Association, 96. vol. 1. no. 2008. 20-27. p. Forrás: https://doi.org/10.3163\%2F1536-5050.96.1.20 [2018. július 27.]

13. BRUNVAND, Amy: Missing Information and the Long Tail. How distributed collection development assures the continued relevance of libraries. = Against the Grain, 18. vol. 4. no. 2006. 34-36. p. Forrás: https://doi.org/10.7771/2380-176X.4917

14. A Fővárosi Szabó Ervin Könyvtár Szervezeti és Múködési Szabályzata. Forrás: http:// www.fszek.hu/rolunk/szervezet/szervezeti_es_mukodesi_szabalyzat/ ?article_hid=34443 [2018. január 18.]

15. A Fővárosi Szabó Ervin Könyvtár 2016. évi statisztikája. Forrás: http://www.fszek.hu/ rolunk/szervezet/statisztika/?article_hid=36170 [2018. január 18.]

16. Statisztikai tükör 2015/80. Könyvkiadás, 2014. KSH. Forrás: https://www.ksh.hu/docs/ hun/xftp/idoszaki/kkiadas/kkiadas14.pdf [2018. január 18.]

Dippold Péter a Fôvárosi Szabó Ervin Könyvtár Központi Könyvtárának igazgatója, mellékállásban 2016-tól az ELTE BTK Könyvtár és Információtudományi Intézet Könyvtártudományi Tanszékének adjunktusa. 2000-2005 között a Könyvtári Intézet igazgatója, majd az Országos Széchényi Könyvtár főigazgató-helyettese. Kutatási területe: a közkönyvtárak fejlesztésének lehetséges irányai az internet korában a trendek tükrében. 